\title{
The Sensation and the \\ Stimulus: Psychophysics \\ and the Prehistory of the Marburg School
}

\section{Marco Giovanelli}

University of Tübingen

This paper analyzes the role played by Fechner's psychophysics — the new science meant to measure sensation as a function of the stimulus - in the development of Marburg Neo-Kantianism. It will show how Cohen, in the early 1870s, in order to make sense of Kant's obscure principle of the Anticipations of Perception, resorted to psychophysics' parlance of the relation between stimulus and sensation. By the end of the decade, Cohen's remarks encouraged the early 'Cohen circle' (Stadler, Elsas, Müller) to pursue what were often sophisticated analyses of the problem of the measurability of sensation. This paper argues that in reaction to these contributions, Cohen shifted his interests towards the history of the infinitesimal calculus in his controversial 1883 monograph, Das Princip der Infinitesimal-Methode. This book, with its characteristic amalgam of transcendental philosophy and history of science, paved the way to what, around 1900, would become the "Marburg school" (Natorp, Cassiver, Görland and others). However, it also interrupted a promising discussion in Marburg on the problem of measurability in science.

\section{Introduction}

In 1912, Ernst Cassirer (1912) contributed to the special issue of the KantStudien that honored Hermann Cohen's retirement-his mentor and teacher, and the recognized founding father of the so-called 'Marburg school' of Neo-Kantianism (Poma [1989] 1997). In the context of an otherwise rather conventional presentation of Cohen's interpretation of Kant, Cassirer made a remark that is initially surprising. It is "anything but accurate," he wrote, to regard Cohen's philosophy as focused "exclusively on the mathematical

I would like to thank Michael Heidelberger for many useful suggestions concerning the first draft of the manuscript. 
theory of nature," (Cassirer 1912, p. 256) as is usually done. A reconstruction of the genesis of Cohen's thought, Cassirer continued, would already refute this interpretation. Actually, "[t] the conditions of the problem, as they were presented to Cohen at that time [die Cohen vorfand], lay at least as much in the critique of physiology as in the critique of physics" (1912, p. 256). ${ }^{1}$ From the "concept of sensation," Cassirer went on, Cohen was initially led to investigate "the [concept] of 'stimulus'," (1912, p. 256) which was regarded only in the second instance as a possible object of physics. I suspect that this allusion to the relation between sensation and stimulus, made only in passing, might escape the attention of most readers. However, Cassirer alluded to an over ten year debate initiated by Cohen and continued by a small group of early sympathizers - a little "Cohen circle" as it might be called, to distinguish it from what only later would become the "Marburg school." Surprisingly, this debate has been completely neglected by historians of Neo-Kantianism, despite being an important line in the development of the history of 19th century philosophy and science.

At the beginning of the 1860 s, the nearly sixty-year-old physicist Gustav Theodor Fechner (1860) claimed to have established a new science, which he called psychophysics. Psychophysics sought to measure sensation on the basis of its functional dependency on the "stimulus," and, at the same time, to present in rigorous form the problem of the relation between the mental and the physical. Starting from Ernst Heinrich Weber's experimental results (Weber 1834, 1846), Fechner suggested that infinitesimal increments of sensation were directly proportional to infinitesimal increments in stimulus and inversely proportional to the amount of the original stimulus. Thus, the function relating sensation to the stimulus would be logarithmic (Fechner 1860 , vol. 2, pp. 9-14). In the successive decades, a debate was sparked among philosophers, psychologists, physicists, and mathematicians over whether sensations could be measured at all (Heidelberger [1993] 2004; Michell 1999). Many, if not most, of the writings of the members of the Cohen circle-nearly forgotten figures like August Stadler, Adolf Elsas and Ferdinand August Müller-were meant to contribute to this debate. These sometimes-sophisticated analyses were in turn inspired by Cohen's early attempt to use psychophysics' conceptual tools to make sense of some of Kant's obscure remarks about the intensive magnitude of sensation in the Kritik der reinen Vernunft.

Michael Heidelberger, in his classic 1993 Fechner monograph (Heidelberger [1993] 2004, Ch. 6), was the first to take the Marburg debate on psychophysics into consideration and to suggest its importance for the formation of the early Cohen circle (Heidelberger [1993] 2004, p. 124f.). However,

1. Henceforth the emphasis in the original has been rendered as italics. 
Heidelberger's contribution, which is "hidden" in a monumental investigation of Fechner's work and its reception, seems to have completely escaped the attention of historians of philosophy. The aim of this paper is to fill what I think is a serious gap in the historical literature on Neo-Kantianism, which has recently been enjoying a renewed interest, especially in the English-speaking world (Beiser 2014; Makkreel and Luft 2009; Luft 2015). Elsewhere (Giovanelli 2016), I have analyzed in detail the role played by Cohen's 1883 "unsuccessful" book on the history of the infinitesimal method, Das Princip der Infinitesimal-Methode (Cohen 1883), in shaping some of the fundamental tenets of the school (in particular the intimate relation between transcendental philosophy and the history of science). In the present paper, I aim to show that it was the early Marburg debate on psychophysics that, in a sort of heterogony of ends, prompted Cohen's interest in the history of higher analysis. This paper is of course very much indebted to Heidelberger's path-breaking contributions. However, by considering the Marburg debate on psychophysics from the perspective of the history of the Marburg school, rather than of Fechner's reception, I hope I will throw a different light on the matter. In particular, in my opinion, there is a missing piece in Heidelberger's reconstruction of the puzzle: Kant's principle of the Anticipations of Perception (A, pp. 166-176; B, pp. 207-218). In my view, this is the key element to understanding the entire debate. The Marburg interest in psychophysics arose from Cohen's early attempt at providing a psychophysical interpretation of Kant's principle, and then faded away when Cohen became convinced that this attempt had failed. It was at this point that he ventured himself into a new interpretation exposed in Das Princip der InfinitesimalMethode. It was the stance towards Cohen's "paradigm switch" that determined the Cohen circle's internal dynamics, which, as we shall see, was more turbulent than it appears in Heidelberger's presentation.

The narrative structure of the paper will be as follows. In the early 1870 s, Cohen, in order to make sense of Kant's obscure principle of the Anticipations of Perception, initially resorted to psychophysics' parlance of the relation between stimulus and sensation (sec. 1). The few remarks that Cohen made on the subject encouraged his early followers (Stadler, Elsas and Müller) to pursue an often-technical analysis of Fechner's psychophysics (sec. 2). In turn, Cohen, inspired by these critiques, realized that psychophysics was not the proper framework for understanding Kant's Anticipations of Perception, which, he claimed, should be interpreted against the background of the history of the infinitesimal calculus (sec. 3). On the one hand, Cohen's infinitesimal turn divided the early Cohen circle into those ready to follow his new course and those who were taken aback by his unorthodox approach to the calculus (sec. 4). On the other hand, Cohen's Das Princip der Infinitesimal-Methode paved the way for the Marburg 
school's interest in the historical fieri of science (Natorp 1912b). At the same time, however, this new course abruptly interrupted a promising discussion in Marburg on the issue of "measurability" in science, a discussion that Cohen himself had somehow unwittingly inspired (sec. 5).

\section{Anticipations of Perception and Psychophysics: Cohen and Stadler}

In the first edition of Kants Theorie der Erfahrung (Cohen 1871), his first Kant monograph, Cohen dedicates several lines to the principle of Anticipations of Perception, the second of the synthetic principles enumerated by Kant in his Kritik der reinen Vernunft. In the second 1787 edition of the Kritik, the principle somewhat cryptically attributes an intensive magnitude to the realitas phaenomenon - the "real" that is the object of sensation. In the first 1781 edition the wording was slightly different. Kant attributes an intensive magnitude to the sensation and to the real that corresponds to it (A, p. 166). Noticing the difference between these two formulations of the principle, Cohen commented: "What is the real as an object of simple sensation, as an intensive quantity, in antithesis to an extensive?": "it is the unity of the stimulus in which we objectify sensation" (1871, pp. 215-16). Kant of course did not use the expression "unity of the stimulus" (1871, p. 217). However, Cohen was convinced that Kant's insistence in the second edition of his opus magnus on the "real" that is the object of sensation, rather than on sensation itself, was motivated by the need to find an objective correlate of sensation: "the intention $[\ldots .$.$] of clar-$ ifying the real as a simple unity of the objectified stimulus seems to me to be the reason for modifying this affirmation in the second edition" (1871, p. 216).

The language of the "physiology of the senses" used by Cohen (1871, p. 215) might not mean much to today's Kant scholar. In contrast, Cohen's insight was enormously influential among his early acolytes, a point that is rarely mentioned in the literature. Cohen's readers at the time probably immediately understood that Cohen's parlance was a reference to Fechner's controversial attempt to measure the intensive magnitude of sensation in terms of its functional relation to the stimulus (Fechner 1860). Similar wordings can be found in Cohen's previous "Herbartian" writings (1868, p. 420). However, Cohen might have learned about this issue from Friedrich Albert Lange's Geschichte des Materialismus (Lange 1866). Lange, by discussing the relation between form and content in Kant's philosophy, mentions Fechner's logarithmic formula for the relation between the sensation as the internal content of consciousness, and the "external (physical) stimulus" (Lange 1866, p. 251).

From 1870 to 1872 Lange was professor of inductive philosophy in Zurich. It was one of his Zurich students, August Stadler (1850-1910), who 
took up Cohen's insights a few years later. Lange himself had recommended Stadler to Cohen, the latter of which being an unknown Privatdozent in Berlin at the time (cf. Cohen 1910a). In Berlin, Stadler broadened his scientific outlook by following the lectures of some of the great scientists of his time: Hermann von Helmholtz, Emil Du Bois Reymond and Ernst Engel; in addition, he attended Cohen's small seminar on the Kritik der reinen Vernunft (Cohen to Lange, May 14, 1873; Lange 1968, p. 372). This seminar deeply influenced him. At the end of 1873, Stadler finished writing a short but influential monograph on Kant's teleology (Stadler 1874), and by October 1875 had already finished a second book, in which he developed Cohen's insight on the transcendental meaning of the a priori (Stadler 1876). Cohen, who in the meantime had succeeded the prematurely deceased Lange in Marburg, immediately elaborated on Stadler's contributions in his 1876/77 book on Kant's ethics (Cohen 1877).

In his 1876 book, Stadler took an original stance towards Kant's Anticipations of Perception. Stadler, like Cohen, also read Kant's second principle as a claim about the psychology of sensation. However, Stadler was not convinced of the success of Kant's attempt to deduce a priori the continuity of the degree of sensation. Thus, he preferred to reformulate Kant's second principle as what he called the "principle of material connection" (Prinzip der materiellen Verknüpfung) (Stadler 1876, Ch. VIII). The principle indicates as an a priori condition the weaker claim that "all sensations must possess an intensive magnitude" (Stadler 1876, p. 65). All sensations must be "over the zero-point of consciousness" (Stadler 1876, p. 65) (that is there are no negative sensations), otherwise the succession of sensations would be interrupted; as a consequence, the unity and identity of consciousness would be compromised and no objectively valid experience would be possible. "Beyond this," Stadler pointed out, Kant took a further step "that I cannot follow" (1876, p. 145). Kant claimed that the increase and decrease of the intensive magnitude of sensation is continuous. Stadler "tried in vain to find a transcendental reason" for this claim, but he had to conclude that "the Kritik leaves it unproven" (1876, p. 145). Whether or not the degree of sensation varies continuously can at most be decided a posteriori, "through the investigation of the single sensations" (1876, p. 72). However, Stadler would soon show that empirical investigations about sensations, far from supporting Kant's claim, actually refuted it.

At the time, nearly two decades after the publication of the Elemente der Psychophysik, the debate about Fechner's result, that physical and subjective intensity are related by a logarithmic function, was alive as ever. In 1877 , Fechner published In Sachen der Psychophysik (1877), in which he defended himself from his numerous and often renowned critics: Hermann von Helmholtz (1867), Ernst Mach (1863), Joseph Plateau (1872), Joseph 
Delbœuf (1873), Ewald Hering (1875), Franz Brentano (1874) and others. Fechner's attempt to measure sensation was based precisely on the assumption that the degree of sensation varies continuously along with the continuous variation of the stimulus. It was this assumption that Stadler wanted to challenge, which, he claimed, Fechner's opponents had not called into question. In February 1878, Stadler finished a brief paper entitled "Über die Ableitung des Psychophysischen Gesetzes," which was published in Philosophische Monatshefte in the same year (Stadler 1878). In contrast to, e.g., Delbœuf (1878), Stadler did not want to deny the quantitative aspect of sensation, but rather to challenge the empirical adequacy of Fechner's logarithmic formula. We shall roughly follow Stadler's derivation of the latter. Although Stadler's procedure is similar though not identical to Fechner's, it remained the model of similar derivations presented by the Marburg group. Throughout this paper, I will follow Stadler (who in turn follows Fechner himself) and indicate the variable corresponding to sensation with $\gamma$, and that corresponding to the stimulus with $\beta$.

Initially Fechner introduced his formula speculatively in the second Appendix of his Zend-Avesta (Fechner 1851, pp. 373-86; cf. Scheerer 1987). However, later, in his Elemente der Psychophysik (Fechner 1860), he presented it as based on Weber's experimental results, in particular those concerning the sensation of weight and touch (Weber 1834, 1846). On the basis of numerous trials on pairwise comparisons of weights, Weber found that subjects do not perceive the absolute difference between them but the ratio of difference to the initial weight. If a one-ounce weight is placed in our hand, we can easily perceive it; however, if two weights of, say, 32 and 33 ounces are compared, we do not perceive the one-ounce difference between them; the ratio $1 / 33$ is too small to be discerned. The same can be said for the difference between eye-estimated lengths, sound pitches, etc. Weber's findings can be summarized in the formula:

$$
\frac{\Delta \beta}{\beta}=c
$$

The constant $c$ depends on the different senses (touch, hearing, etc). In this formulation of Weber's results, there is no mention of sensation. In order to establish a functional relation between sensation and stimulus, Fechner made a further assumption. He postulated that the "difference sensation" (Unterschiedsemempfindung) or "contrast sensation" (Contrastempfindung)—which arises when the difference of two stimuli becomes "just noticeable" - is proportional to the "sensation difference" (Empfindungsunterschied), the difference between the two corresponding sensations (Fechner 1860, vol. 2, 
p. 85). This assumption is nothing but the psychophysical analogon of the definition of equal temperature differences in terms of equal volumes of expansion in the theory of heat (Tannery 1875a, 1875b). To put it more precisely: if the just-noticeable stimulus-increase with respect to the original stimulus is constant $\Delta \beta / \beta=c$, then the corresponding "difference sensation" is constant $\Delta \gamma=c^{\prime}$. Setting $c=k c^{\prime}$, the "just-noticeable differences" between stimuli (j.n.d.) might be used as a unit of measurement; the number of sensation differences $\Delta \gamma$ between two stimuli is $k$ times the number of j.n.d. $\Delta \beta$ / $\beta$ between them. In this way one can write Weber's experimental findings in the form of a functional relation between stimulus and sensation:

$$
\Delta \gamma=k \frac{\Delta \beta}{\beta} \text { where } k=\frac{c^{\prime}}{c}
$$

Notice that this equation does not appear in Fechner's writings (see below in sec. 3). In Stadler's reconstruction, however, Fechner started from this equation and postulated that it is valid for every change of sensation, however small; that is, it is also valid for the so-called "unconscious sensations" that are caused by a stimulus which is not sufficient to raise them to consciousness (e.g., the increase from 32 to 33 ounces). Fechner appealed to what he called an "a priori valid mathematical auxiliary principle [Hülfsprincip]" (Fechner 1860, p. 40): what is true for finite differences ought to also be true in the limit. Then he substituted the finite increments $\Delta \beta$ and $\Delta \gamma$ with the infinitesimally small increments $d \beta$ and $d \gamma$. The simple relation (ii) between two units of measure turned into an informative differential equation, the so-called Fundamentalformel:

$$
d \gamma=k \frac{d \beta}{\beta}
$$

The next step was to derive an integral formula containing an expression for the measurement of sensation. This is a matter of more or less elementary differential and integral calculus. One first calculates the indefinite integral of eq. (iii) (i.e., without upper and lower limits):

$$
\int d \gamma=\int k \frac{d \beta}{\beta}+\text { Const }
$$

By consulting a table of integrals one can easily find that the integral of a fraction whose numerator is the differential of the denominator is the 
natural logarithm (that is, a logarithm with base $e=2.7182 \ldots$ ) of the denominator:

$$
\gamma=k \ln \beta+\text { Const }
$$

To eliminate the constant of integration one evaluates the integral between definite limits. Fechner chooses as the lower limit $\gamma=0$, where the sensation begins (that is it becomes conscious) and disappears and the correspondent $\beta_{0}$, that is, the threshold of stimulus below which there is no perception:

$$
\int_{\gamma_{0}}^{\gamma} d \gamma=\int_{\beta_{0}}^{\beta} k \frac{d \beta}{\beta}
$$

The sensation $\gamma$ - or more precisely the difference of two sensations $\gamma_{0}-\gamma$ which corresponds to the differences of two stimuli $\beta-\beta_{0}$ - can be measured as the definite integral, that is, as a summation of infinitesimally small sensation increments $d \gamma$ which corresponds to the summation of infinitely small stimuli increments $d \beta$. According to eq. (v) this is of course equivalent to $\gamma-\gamma_{0}=\ln \beta-\ln \beta_{0}$. For a well-known $\operatorname{logarithmic}$ identity, the difference of the logarithms of two numbers is the logarithm of their ratio. Thus Fechner's final equation is the following:

$$
\gamma=k \ln \frac{\beta}{\beta_{0}}
$$

Sensation $\gamma$ is not simply the logarithm of the stimulus $\beta$, but of the latter expressed in terms of its threshold value $\beta_{0}$, the first unit stimulus, from which the zero point where the sensation begins and disappears (Fechner 1860, vol. 2, p. 13). After the initial value $\left(\beta_{0}\right)$ and the unit of measurement $\left(\beta_{0}=1\right)$ have been specified, sensation can then be measured as an accumulation of j.n.d. Thus, Fechner's formula is both a law of nature and a measurement formula at the same time (cf. Heidelberger [1993] 2004, p. 206; Heidelberger 1993).

After roughly presenting Fechner's derivation in this way, Stadler pointed to a simple but serious conceptual difficulty that it entails. According to Weber's findings, if one imagines the stimulus gradually increasing from a weight of, say, 32 ounces to twice that, then not all of the infinite possible values between 32 and 64 ounces can be perceived, rather only those for 
which the eq. (i) or $\Delta \beta=c \beta$ holds. We can perceive the difference between, say, 32 and 42 ounces, but not between 32 and 33 ounces: "not every $\Delta \beta$ corresponds to a variation of the sensation, rather $\Delta \gamma$ remains zero for all values > $c \cdot \beta$ " (Stadler 1878, p. 219). When Fechner, relying on his mathematical auxiliary principle, introduced eq. (iii) — that is, he substituted finite differences $\Delta \beta$ and $\Delta \gamma$ with infinitesimally small ones $d \beta$ and $d \gamma$-he contradicted Weber's results rather than building on them.

Of course this objection is valid only if one equates sensation with conscious sensations, as Stadler explicitly does. In this case one can claim that Weber's experiments have shown that no sensation change $\Delta \gamma$ corresponds to a very small stimulus variation $\Delta \beta=d \beta$ : "Weber's law is an empirical law and it is valid only for the real, empirically given sensations, and not so-called unconscious ones" (Stadler 1878, p. 220). As a consequence, we are not allowed to "represent the reciprocal correlation of the stimulus and of the sensation through a continuous function or a curve" $(1878$, p. 220). In Fechner's conception, stimulus and sensation are related by the natural exponential function $\gamma=e^{\beta}$. Such a function can be plotted on a Cartesian coordinate system by a smooth curve (looking like half a parabola) which increases dramatically over its domain, since $\gamma$ increases faster as $\beta$ increases: equal units on a sensation scale correspond to progressively greater units on an external physical scale. However, according to Weber's findings, if we represent a small variation of the stimulus $(\Delta \beta<c)$ on the $x$-axis, then no variation of the sensation $(\Delta \gamma)$ would correspond on the $y$-axis: "The sensation progression," in Stadler's words, "then has the form of a stair with steps of increasing width" (1878, p. 220).

"The essence of the relation between $\Delta \beta$ and $\Delta \gamma$," as Stadler summarized his critique of psychophysics, "is discontinuity. The logarithmic curves, with which one attempts to represent the psycho-physical law, lack empirical truth" $(1878$, p. 223). However one might judge this technical result, its philosophical implications seem hard to fathom at first. However, the philosophical intent of Stadler's critique of Fechner became more perspicuous in a paper Stadler finished in June of 1880 and published in the same year in the Philosophische Monatshefte, "Das Gesetz der Stetigkeit bei Kant" (Stadler 1880). Stadler showed that Kant had an ambiguous attitude on the question of the continuity of the intensive magnitude. In the Anticipations of Perception, Kant claims that the intensive magnitude of sensation is continuous only in the weak sense, that between every degree and nothing, one can always think of another arbitrary possible smaller degree. Nothing can be said about the continuous increasing or decreasing of the variation of degree, which is an empirical question (B, pp. 212-13). However, in the Beweis of the second Analogy of Experience, Kant seems to defend the stronger claim, that the intensive magnitude of sensation 
arises from 0 to a certain degree in a continuous manner, running through all actual intermediate degrees (B, pp. 255-56).

At first sight, Stadler's paper seems to lack theoretical ambition, and it is based on a detailed textual analysis of Kant's passages on continuity. However, though "only in passing," he does note "that modern psychology has not offered any reason to reshape Kant's concept of the degree of sensation" (Stadler 1880, p. 585). Modern psychophysics does not permit any a posteriori demonstration of what Kant attempted in vain to demonstrate a priori. Psychophysics postulates that the process of the emergence of a sensation runs through all intermediate degrees, even if this passage is so rapid that it remains unnoticed. However-and this was the result of Stadler's 1878 paper - this postulate, far from being valid a priori as Fechner claimed, can probably be proven wrong a posteriori: "as far as intensity is concerned, in my opinion, psycho-physical research has instead shown the discontinuity in psychical transition in relation to the continuous growth of the stimulus" (Stadler 1880, pp. 585-6). Experience seems to show that the stimulus, e.g., a weight, can be increased to a certain degree without causing any change in the corresponding conscious sensation.

Cohen seems to have immediately appreciated Stadler's result. In a letter to Stadler on February 24, 1881 Cohen claimed that he now "fully agreed" with his "Stetigkeit" (that is, Stadler 1880). However, he added: "I have outlined a formulation of the Anticipation in which your previous concerns seem to be acknowledged and at the same time eliminated" (Cohen to Stadler, February 24, 1881; Cohen 2015, pp. 128-9; my emphasis). This only recently published letter is central to my account. It shows that a fundamental "paradigm shift" happened at this point. On the one hand, Cohen recognized that Stadler's objections were justified against Kant's a priori deduction of the continuity of the degree of sensation. On the other hand, one can surmise that at that time Cohen probably started to realize that Kant's Anticipations of Perception should be understood from a quite different perspective, outside the framework of psychophysics. We do not have further information on what exactly Cohen had in mind. His next letter to Stadler is dated months later in October and includes the first mention of "our new Privatdozent Dr. Natorp"; in particular, Cohen announced the latter's new writing "which is thorough a[nd] clear" (Cohen to Stadler, October 30, 1881; Cohen 2015, p. 131). Paul Natorp's habilitation thesis on Descartes (later published as Natorp 1882a) had just been accepted and he had given his inaugural lecture on Leibniz a few days earlier (Natorp 1881). Natorp's early works in Marburg revealed that Cohen was reorienting the interests of his circle towards the "prehistory of criticism" and its connection to the history of science (Natorp 1882b, 1882c). In particular, Cohen might have already realized that the Anticipations of Perception should be understood not 
in the context of the epistemology of empirical psychology, but by investigating the historical roots of Kant's principle in the development of modern mathematics and physics.

\section{Elsas, Müller and the Early Cohen Circle in Marburg}

That Cohen initially attempted to interpret Kant's second principle against the background of Fechner's psychophysics might surprise today's Kant scholars. However, this approach was part of a vast research program that Cohen put forward just after he succeeded the deceased Lange in Marburg, becoming the first Jewish philosophy full professor at a German university. According to the guideline of the Prussian Kultusministerium, the philosophy faculty in Marburg used to offer scientific Preisaufgaben (essay prizes) with the intent of supporting students (Sieg 1994, p. 130). The call for papers launched by Cohen for the 1880/1881 prize (cf. Holzhey 1986, vol.1, p. 381) required the candidate to "[e]xplain Kant's mathematical principles"; the first principle, the Axioms of Intuition with reference to "the new science of space," that is, non-Euclidean geometry; "the second principle," the Anticipations of Perception, "should be evaluated with respect to the problem of psychophysics" (cited in Holzhey 1986, vol.1, p. 382; my emphasis).

The recipient of the prize was the physicist Adolf Elsas (1855-1895), who, after his dissertation written under Helmholtz's guidance in Berlin (Elsas 1881), was working as an assistant at the Marburg physical-mathematical institute. In his referee report, Cohen praised Elsas' secure knowledge of Kant's philosophy (Sieg 1994, p. 131). Concerning the treatment of Kant's first principle, Cohen appreciated Elsas' ability to grasp the philosophical implications of "the Riemmann-Helmholtz speculations" beyond technicalities; with regard to the second principle, Cohen recognized that Elsas presented "the correct point of view for the appreciation of the psychophysical problem" (Holzhey 1986, p. 23n86).

The question of the measurability of psychical magnitudes was hotly debated among philosophers at that time. An influential scholar like the great historian of Greek philosophy (and proto-neo-Kantian) Eduard Zeller, had just published a discussion of the issue in the proceedings of the Prussian Academy of Science (Zeller 1881). The dissertation of Ferdinand August Müller (1858-1888), of which Cohen was the main supervisor, further testifies that this was one of the main philosophical concerns in Marburg. In his Gutachten, Cohen emphasized that, after Stadler's technical objection against Fechner's law, Müller was able to show "that in the very problem of establishing a functional relation between stimulus and sensation there is an epistemological mistake" (Holzhey 1986, vol.1, p. 22).

In October 1881, Müller finished transforming his dissertation into the booklet Das Axiom der Psychophysik (Müller 1882). The title refers to the fact 
that Müller distinguished the "axiom of psychophysics," that is, Fechner's claim that there is a functional relationship between stimulus and sensation, and the "problem of psychophysics," the search for the particular form that such a functional relationship actually assumes (e.g., logarithmic law, power law, etc.). Instead of attacking Fechner's solution of the problem as Stadler had done, Müller wanted to strike the heart of Fechner's enterprise by questioning the very idea that a functional relationship exists at all.

Müller recognized the importance of Stadler's critique of Fechner's law. "Such a sharp objection," he wrote "would alone be capable of overthrowing Fechner's entire construction of formulas [Formelgebäude]" (Müller 1882 , p. 23), if the latter were based exclusively on Weber's result, that is, only on the "method of just-noticeable differences". However, Müller argued, "[t] this is not the case" (Müller 1882, p. 23). Beyond the experiments that concern the just-noticeable differences, one must take into account the "method of more-than-noticeable differences," or the method of bisection. Müller showed that Delbœufs (1873) repetition of Joseph Plateau's (1872) experiments on color differences allow dividing an initial interval between two largely different perceived magnitudes of a sensation into equal subintervals. Once equally-appearing intervals are defined, according to Müller, Fechner could introduce the hypothesis expressed by Weber's fraction (ii). Müller argued that if one accepts this hypothesis, as Stadler did, then "the passage to the fundamental formula containing the infinitely small values $d \beta$ and $d \gamma$ is irreproachable" (Müller 1882, p. 25).

Müller's defense of Fechner's derivation (see however Heidelberger [1993] 2004 , p. 215) was of course meant to strategically shift the attention to a more fundamental question. The shortcomings of psychophysics are not physical-mathematical, but, as Müller put it, "transcendental."

Müller uses the term transcendental according to the interpretation that Cohen had laid down a few years earlier in the first part of his book on Kant's ethics (Cohen 1877). As is well known, in Cohen's view, Kant's transcendental method proceeds bottom-up from the fact of the mathematical science of nature as it is historically given in the "printed books," to the conditions of its possibility (cf. Cohen 1877, p. 77). The same approach must be applied to psychophysics. Quantitative psychologists assumed as a fact that the psychological attributes that they aspired to measure are quantitative. However, this alleged fact must be transformed into a "problem", and its possibility must be carefully evaluated.

Müller's considerations, unfortunately, presuppose that the reader has already bought into quite a lot of Kant's philosophy. In particular, not surprisingly, Cohen's early interpretation of the Anticipations of Perception plays a major part in Müller's line of argument. Müller conceded that Kant's two formulations of the principle are confusing to say the least. Does Kant 
claim that sensation has intensive magnitude, or the real, which is the object of sensation, or both? "The relations between sensation and the real, which corresponds to it in the object, is not expressed with full clarity" (Müller 1882, p. 51). In Müller's view, Cohen had made a fundamental step toward solving the riddle: "by defining the real that corresponds to sensation in the object as 'stimulus', Cohen developed in a highly significant way Kant's doctrine of the intensive magnitudes" (Müller 1882, p. 55). On the one hand, Cohen obtained a hermeneutic elucidation of Kant's different formulation of the Anticipations of Perception in the two editions of the Kritik der reinen Vernunft; on the other hand, he provided an epistemological clarification of the ambiguous notion of stimulus. The stimulus does not arouse or cause sensation, the stimulus is the object of sensation or it is the objectified sensation (Müller 1882, p. 53). The main consequence of Cohen's approach, in Müller's view, is that it is not the sensation that has intensive magnitude, nor the sensation and the stimulus, but only the stimulus.

According to Müller, "physics measures intensive magnitudes and it is therefore the task of physics to measure the magnitude of the stimulus" (Müller 1882, p. 55). Using a Bunsen's grease-spot photometer, for instance, one can establish that the illuminance of the photometer screen due to the source $S$ located a distance $d$ from the photometer is equal to the illuminance of the screen due to the source $S^{\prime}$ located a distance $d^{\prime}$ from the screen when the grease spot on the photometer's screen becomes invisible $\left(S: d^{2}=S^{\prime}: d^{\prime 2}\right)$. After choosing a luminous intensity of a standard candle (Normalkerze) as a unit, it is possible to construct the luminous intensity scale with equally spaced units along the scale. Then one can establish "how many standard candles at the same distance one would need to obtain the same effect as the light that we want to measure" (Müller 1882, p. 54). Using a Kantian terminology (B, pp. 201n), Müller claimed that intensive magnitudes can be measured through a coalition of parts, rather than through aggregation as in the case of extensive magnitudes (Müller 1882, p. 54).

In Müller's reconstruction, Fechner attempted to achieve something analogous for the intensity of sensation. As we have mentioned, the trick was to postulate that the difference sensation or contrast sensation (Contrastempfindung) for two stimuli (the just-noticeable relative increase in stimulus), was proportional to the sensation difference (Empfindungsunterschied) (the difference between the two corresponding sensations). However, Müller objected, this has the "absurd" implication that equal stimuli would produce no sensation (Müller 1882, p. 106); but even if one sets aside this issue, there is still no proof that the proportionality postulated by Fechner holds (Müller 1882, p. 18). However, without this assumption sensation intensities cannot be transformed into a class of measurable intensities. Instead of speaking of contrast sensations that vary according to their intensity, Müller concluded, 
we can at most speak of contrast feelings (Contrastgefüble) that vary according to their character (Müller 1882, pp. IV, 104, 106). In other terms, the equality and difference among, say, luminosities can be organized only in a nominal scale assigning different names to different types of contrast feelings (say, dark, shadowy, bright, luminescent, etc.; cf. Philippi 1883, p. 585ff. See Müller 1882, pp. 106-115, for more sophisticated examples).

Thus, contrary to Fechner's ambitions, Müller believed himself to have shown that "sensation cannot be expressed in numbers at all," i.e., it cannot be measured (Müller 1882, p. 58). The stimulus can be measured, but one can speak of the magnitude of sensation only in a figurative sense. As a consequence, no functional relationship can be established between them. Fechner's indirect scaling method, in which the sensation differences are measured by putting j.n.d in a row between stimuli becomes powerless (Müller 1882, p. 58). The conclusion is of course that the axiom of psychophysics, the very claim that a functional relationship exists between the magnitude of sensation and the magnitude of the stimulus, is flawed: "sensation is not a function of the stimulus, but the stimulus is the object of sensation" (Müller 1882, p. 56).

Müller's epistemological reflections constitute only a relatively small portion of the book. The latter includes further detailed analyses of Weber's and Charles Delezenne's (1826) experiments (II.1 and II.2), of Helmholtz's (1877) analysis of sound sensations (II.3-5), of Georg Elias Müller's (1878) development of the right or wrong cases method (III.1), Delbœuf's (1873) measurement of fatigue (III.2), and Hering's (1875) work on spatial and temporal sensations (III.1). This material cannot be considered here. What is relevant in this context is that Müller displayed a solid technical knowledge of the topic. Thus, Fechner himself took the time to reply to the "mathematically as well as philosophically trained author" (Fechner 1882, p. 324).

In 1882, Fechner published Revision der Hauptpuncte der Psychophysik (Fechner 1882), a newly articulated defense of psychophysics against an apparently never-ending series of new critics, including several philosophers like Zeller $(1881,1882)$ and Johannes von Kries (1882). If Zeller insisted that sensation magnitudes cannot be measured in practice, von Kries thought that they cannot be measured in principle; Müller, as we have seen, raised the more radical "quantity objection" that there are no sensation magnitudes at all (cf., e.g., Michell 1999, p. 40ff.). Against Müller's argument "from Kantian principles" (Fechner 1882, p. 325), Fechner pointed out that no one can deny that sensations of the same type (light, acoustic, etc.) can be said to become stronger or weaker. Müller can regard contrast sensations or sensation differences as mere contrast feelings, if he wants to. However, Fechner believed himself to have shown that if one defines sensation differences as proportional to "difference sensations," one can achieve 
measurements that are empirically correct. "What should I care about Kantian definitions" (Fechner 1882, p. 325), he concluded. ${ }^{2}$ Müller is correct in claiming that quantities can be compared only via a unit of measure: "and exactly in this way my measurement formula measures sensation, even if not directly, but through the mediation of its functional relations with the stimuli" (Fechner 1882, p. 326).

In his review of Müller's book, Elsas (1883a)—who in the meantime had become Privatdozent in Marburg (Elsas 1882)—defends his Marburg colleague on this point. If sensation intensities are ordinal (weaker and stronger), this does not mean that they are measurable, that a certain sensation is five or six times stronger than another one. Neither this measurability of a quantity can be inferred from the fact that it is set in functional relation to a measurable quantity. For instance, the welfare of a nation depends, say, on its morality (Sittlichkeit); if one concedes that the former is measurable, this does not mean that the latter is too (Elsas 1883a, pp. 130-31). Fechner's objection to Müller, according to Elsas, reveals that the problem was much deeper. Fechner and his followers should undertake a serious discussion to establish what a "measurable magnitude" is in general (1883a, p. 131). Physics could be successful for a long time without raising this question, but empirical psychology made an epistemological analysis of the issue unavoidable.

Elsas's review is worth mentioning because it reveals the background against which this issue was understood within the Cohen circle. According to Elsas-who was probably summarizing the results of his prize essayKant's transcendental question about the possibility of mathematics and physics should be extended to the new sciences that were gaining ground in the second half of the 19th century. "Is metageometry, is psychophysics a possible science?" (Elsas 1883a, p. 127). The issue, as Cohen has shown, is not a physio-psychological one; neither the origin of the representation of space nor the organization of our sensibility are at stake. The question is, "on which transcendental foundations (that is, on which conditions making the knowledge possible) is the necessity of mathematical knowledge based?" Müller, embracing "Cohen's conception of the transcendental" (Elsas 1883a, p. 127), has ventured to submit psychophysics to such a critical investigation.

In mathematics and physics we establish functional relationships among magnitudes. The stimulus is clearly a magnitude that can be measured. "Can the sensation also be measured? Yes or no? The answer to this simple question decides the possibility of psychophysics" (Elsas 1883a, p. 130). Despite providing an overall positive review of the book, Elsas however did

2. For the importance of Fechner's answer to Müller, cf. Heidelberger [1993] 2004, p. 240. 
not fully agree with Müller's philosophical conclusions. Elsas, like Müller, subscribed to Cohen's identification of Kant's "real which corresponds to sensation" with the stimulus. However, Elsas denied that one can attribute an intensive magnitude to the stimulus: "Physics measures intensities only as extensive magnitudes; the intensity of a physical phenomenon, e.g., of sound, of a light source, of a force is never an intensive magnitude" (1883a, p. 133). Intensive magnitudes are measurable only indirectly through their extensive effects. ${ }^{3}$

\section{Cohen: From Psychophysics to the History of the Infinitesimal Method}

When Elsas published his review of Müller's book, Cohen had already come to the conclusion that his interpretation of the Anticipations of Perception, in which the real was identified with the stimulus of psychophysics, was not satisfying. Psychophysics was simply not the right framework for making sense of Kant's Anticipations of Perception. As we have mentioned, at the beginning of 1881, Cohen wrote to Stadler that he envisaged a way to acknowledge, and at the same time overcome, the latter's objection that, contrary to Kant's claim, the degree of sensation probably varies discontinuously. The most reliable, though indirect, source at our disposal for concretely understanding what Cohen had in mind is probably Stadler's then-new monograph, Kants Theorie der Materie (Stadler 1883)—possibly the first monograph on Kant's Metaphysische Anfangsgründe der Naturwissenschaft (Kant 1786).

Stadler still fully works within the framework built by Cohen and discussed by the early Cohen circle. As Stadler writes, "Cohen, very happily, called 'stimulus' the objective correlate of the intensive magnitude" (1883, p. 60). The magnitude that corresponds to the stimulus of the intensive magnitude of sensation would thus be called the "magnitude of the stimulus" (1883, p. 60). Stadler agreed with Müller that "only the stimulus can be measured, not sensation"; however, this did not mean that "intensive magnitude can only be attributed to the stimulus," as Müller claimed (Stadler 1883 , p. 248n24). For Stadler, only sensation has intensive magnitude, but this is an internal psychological determination, which "in its own nature is not measurable" (Stadler 1883, p. 61). Stadler agreed with Elsas that intensive magnitudes are measurable only through their causal product of extensive ones.

Stadler attempted to apply these conceptual tools to Kant's work, giving of a sort of psychophysical interpretation of some of the key elements of his philosophy. Kant's Gegebenwerden and the Afficirtwerden can be interpreted

3. This is, by the way, a quite Kantian point of view, see, e.g. Ak., 18:322; 28:425. 
as, in a first approximation, the "representation of the dependence of the change of sensation on the outside" (Stadler 1883, p. 53); more precisely this dependence- "which today one would call psychophysical" (1883, p. 58) - means "the emergence of a degree of consciousness, an intensive magnitude" (1883, p. 59). The objective correlate of the intensive magnitude, as suggested by Cohen, is the stimulus. In Stadler's view, the stimulus of sensation should ultimately be thought of as motion. This is what Kant meant when he claimed that the object of the external senses must be motion "because only thereby [through motion] can these senses be affected" (Ak., vol. 4, p. 477). The differences between sense qualities should be ultimately dissolved in the differences between motions. In Stadler's reading, this is nothing but "the principle of physiology that all external stimuli of the sensations must be motions" (1883, p. 8), which, through the peripheral nervous system are passed to the central nervous system (cf. Stadler 1878, p. 223; see also Wundt 1874, p. 277).

Stadler notices further that, in the Beweis of the Anticipations of Perception, Kant used the expression "moment" to indicate the "reality as cause" and, in particular, as the "cause of sensation," as something that exerts an influence on the senses (B, p. 211). "Moment" is for Kant the moment of acceleration, an infinitely small variation of velocity. According to Stadler, the term moment reveals that what Kant called "influence on the senses', the 'stimulus'" (1883, p. 60) is nothing but the effect on what in physics we call force. The "moment is the magnitude of the force that corresponds to the intensive magnitude of the sensation" (1883, p. 60). The magnitude of the force and intensive magnitude are correlated, but not identical. Force can be measured only through its extensive effects. The intensive magnitude is given in consciousness, it is a "subjective evaluation" of the stimulus, and cannot be measured (Stadler 1883, p. 61).

Stadler conceded that there are passages where Kant seems to attribute intensive magnitude not to sensation, but to physical determinations like velocity (cf. Ak., vol. 4, p. 540-41). However, he claimed, one should resist confusing this intensive magnitude with the intensive magnitude of sensation. According to Stadler, Kant "did not want to identify it [the intensive magnitude of velocity] at all with the intensive magnitude, which corresponds to reality" (1883, p. 37 ; in the sense of the category of reality). The definition of the velocity as an intensive magnitude, Stadler pointed out, was only an analogy used to emphasize that the magnitude of velocity is not composed of parts, as the magnitude of space and time is.

Stadler took some pains to interpret away the passages that could support the opposite reading. E.g., he comments on Kant's reflection with the title 'Über das Moment der Geschwindigkeit im Anfangsaugenblick des Falls' (Ak.,vol. 14: Refl. 67; 1788-1791). Here Kant attributes an intensive 
magnitude to the moment of velocity - that is, the tendency to fall downward at the beginning of a falling motion - and conceives of the finite motion as a summation of infinitely many "moments" (Ak., vol. 14, p. 495; Refl. 67). Stadler warned that one should not try to read passages like these as Kant's attempt to provide a foundation for the "objective validity of the differential calculus" (1883, p. 39). Interpreters committed to such a reading "would be in contradiction with the view that Kant expressed of the infinitesimal method" (1883, p. 39). In general, in Kant's work, continuity means infinite possibility of division, not composition from actual, though infinitely small parts. Stadler concludes polemically that, "those who make the intensive magnitude correspond with the differential confuse the form with the content" (1883, p. 39).

Although Stadler never mentioned Cohen explicitly, Cohen himself later read this last claim in particular as being directed towards his upcoming book (Cohen 1910a). Stadler's monograph was finished in March (Stadler 1883, p. IV). According to Cohen's later recollections, Stadler stayed in Marburg in the summer of 1883 while Cohen was working on his Das Princip der Infinitesimal-Methode (Cohen 1883). The Vorwort of Cohen's book is dated August 1883 (Cohen 1883), but the book was sent to print only in midOctober (Cohen to Natorp, September 27, 1883; CN, Br. 1, 148). Reading the drafts of their books, Stadler and Cohen probably realized that one of them put forward precisely what the other vehemently rejected. Edited by that time, Cohen had completely abandoned the framework of psychophysics, which had enjoyed so much success among his acolytes. He became convinced that Kant's second principle could be understood precisely by looking at the connection between the concepts of moment, intensive magnitude and reality, which was suggested by the Kant passages mentioned by Stadler. According to Cohen, by establishing this connection, Kant had expressed philosophically in his principle of Anticipations of Perception the problem that Galileo, Leibniz and Newton had tried to answer mathematically when they introduced a new type of quantities, namely, infinitesimally small quantities.

I cannot enter into the details here of this highly obscure book and its tormented reception, which I have described elsewhere (Giovanelli 2016). What I would like to emphasize is that Cohen explicitly recognized that it was Stadler's critique of a possible psychophysical reading of Kant's Anticipations of Perception that changed his mind: to understand "what was new and valuable in Kant's conception of the intensive magnitude," Cohen wrote, it was necessary to become aware of "the deficiencies in its foundation and presentation, which A. Stadler had first emphasized" (Cohen 1883, p. 105). Stadler showed the failure of psychophysics' attempt to present the intensive magnitude of sensation as the differential $d \gamma$ (Cohen 1883, 
pp. 159-60). ${ }^{4}$ Cohen, however, at the turn of the 1880s, must have come to realize that what psychophysics had failed to achieve in the case of sensation could still be established on another basis. The intensive magnitude of sensation was not at stake in Kant's Anticipations of Perception, but rather the intensive magnitude of physical determinations such as velocity. It was in the attempt to give a mathematical counterpart to the intensive magnitude of velocity that the differential was introduced. Kant's principle was the philosophical expression of this historical fact.

The passage from one interpretative framework to the other seems to be based more on an association of ideas than on a proper argument. However, the role played by the discussion of psychophysics is confirmed by Cohen's own reconstruction of the path that led him to rethink the interpretation of Kant's second principle in the revised and greatly augmented edition of his Kants Theorie der Erfabrung (Cohen 1885), which was finished in August 1885. Cohen recalls that "[i]n the first edition of this book" (cf. Cohen 1871 , p. 46), he had attempted to identify the real that corresponds to sensation with "the "unity of stimulus, in which we objectify sensation", (1885, p. 436). However, he now recognized that "this expression, although useful to encourage further reflections, was too psychological to be maintained" (1885, p. 436). What is at stake is not "the unit of stimulus," but the "the unit of motion" (1885, p. 436). It is precisely in those passages mentioned by Stadler that Kant, by establishing a relation between reality, intensive magnitude, and the mathematical/physical concept of moment, expresses the very problem that the discoverers of the infinitesimal calculus had to solve to make motion an object of scientific inquiry: "Consequently Galilei and Leibniz talk of the infinitely small as an intensive magnitude" (Cohen 1885, p. 427). Kant, Cohen claims, does not even have to emphasize this connection since it was obvious to his readers (Cohen 1883, p. 105).

Again Cohen recognized that it was Stadler's work on psychophysics that led him to completely rethink his own interpretation of the Anticipations of Perception. In Cohen's words, Stadler "rightly opposes the continuity of sensation as an a priori determination" (Cohen 1885, p. 437). Not only is there no pure transcendental foundation for the continuity of sensation; Stadler also demonstrated that empirical studies on the psychology of sensation are even less capable of demonstrating a posteriori that sensation grows in a continuous way. However, Stadler "only looks for the pure transcendental foundation he is missing in the sensation" (Cohen 1885, p. 437). He did not realize that "the "pure transcendental

4. See cf. Heidelberger [1993] 2004, p. 222 for more on Cohen's critique of psychophysics in Das Princip der Infinitesimal-Methode. In my perspective, the interesting part of the story is the role psychophysics played in Cohen's work before this book was written. 
foundation" he was looking for cannot be found "in the sensation, but only for the sensation" (Cohen 1885, p. 437; my emphasis). That transcendental ground should be found "in the new and autonomous mode of magnitude, which in the infinitesimal method reveals itself to be fruitful for the constitution of the object in his mechanical meaning" (Cohen 1885, p. 437). In other words, Stadler still thought that psychophysics offered the conceptual framework for understanding the problem Kant was facing. According to Cohen, however, this framework was inadequate for understanding Kant's concept of the "intensive": "the so-called intensity of sensation must absolutely be distinct from the intensive magnitude or reality of sensation" (1883, p. 156).

Elsas, in his 1885 review of Stadler's 1883 book (1885b), points out clearly where Stadler was no longer in accordance with Cohen's new approach to Kant's second principle. Stadler considered "motion as the stimulus of sensation" (1885b, p. 146); according to Elsas, however-even if there is some textual evidence to apply this psychological interpretation to Kant-the central point is different: transcendental philosophy should try to explain what makes general mechanics a science and thus what makes motion a legitimate object of scientific inquiry: "The task is to explain the fact of science, the fact of general mechanics" (1885b, p. 146). The relation between motion and sensation is philosophically secondary, if not irrelevant. "Maybe the author should have further developed the concept of intensive magnitude and its relation to the category of reality" (1885b, p. 146); "the elementary concepts of mechanics," Elsas continues alluding to Cohen's work, "already offer some indication in this direction" (1885b, p. 146).

\section{The Dissolution of the Cohen Circle}

Stadler's publication rate fell drastically in the ensuing years, possibly for health reasons, and we do not have textual evidence of his possible counterobjections. However, we know that he never agreed with Cohen's new course, even if he himself unwittingly had brought it about; their friendship, however, never suffered (Cohen 1910a). Elsas continued to publish, as a physicist (Elsas 1883b, 1885a, 1886c, 1887), a reviewer of philosophical publications $(1884,1885 \mathrm{~b})$ and as a high quality science popularizer (1886a). Moreover, after Fechner's 1882 Revision der Hauptpuncte der Psychophysik (1882), Elsas returned to psychophysics; in 1886 he published his philosophical reflections on the topic in a little pamphlet, Über die Psychophysik (1886b). Elsas continued the early Marburg debate on the measurability of sensation and at the same time made some timid attempts to integrate it into the new approach taken by Cohen in his 1883 monograph. 


\subsection{Elsas' Über die Psychophysik}

Elsas organized his book around two questions: 1. "Are Fechner's measuring formulas mathematically and physically correct and derived from the data?" (Elsas 1886b, p. VI). 2. "Is psychophysics in the sense of Fechner possible in general?" (1886b, p. VI). Elsas answered both these questions with a resounding "no." In this sense Elsas was more radical than both Stadler and Müller. In the language introduced by the latter, he intended to criticize both the problem and axiom of psychophysics. In what follows, for reasons of brevity I will concentrate on the third and final part of the book, in which Elsas dealt with question 2., which is of course the one richer in philosophical implications (see also Heidelberger [1993] 2004, p. 229ff).

After a long digression on du Bois-Reymond's (1882) theory of quantity (Elsas 1886b, pp. 50-61; cf. Darrigol 2003, p. 540)—Elsas argued against the very possibility of measuring the sensation via its functional relation with the stimulus. Elsas defined the concept of function as the production of quantity from other quantities. For instance, the area of a triangle is a function of two variables, base and altitude (Elsas 1886b, p. 61). However, something different is meant when one says that, according to Ohm's law, the current through a conductor between two points is a function of the voltage across the two points and a constant of proportionality, the resistance (Bois-Reymond 1882). According to Elsas, in the latter case we assume, at least implicitly, that there is a causal connection that serves as the basis of the functional relationship (Elsas 1886b, p. 61; cf. Heidelberger 2010). The volume of Knallgas or oxyhydrogen that can be produced by water electrolysis in a given amount of time measures the electric current because the current causes the electrolysis; or, to take a simpler example, the thermometer measures temperature because equal temperature differences cause equal expansions of the mercury column, etc.

No such causal connection can be found between stimulus and sensation. Thus, Fechner has no real reason to claim that equal difference sensations are proportional to equal sensation differences. The question is not merely epistemological; Elsas showed that, without having a causal connection as a guide, it is easy to lose grasp of the mathematical derivation. Let's grant Fechner that his "constant $k$ has the same meaning as the practical measuring unit for sensation" (Elsas 1886b, p. 17); then inconsistencies arise in his system of formulae. According to eq. (ii), $k$ is the value of the sensation difference $\Delta \gamma$ that corresponds to $\Delta \beta: \beta=1$, that is, to a doubling of the initial stimulus $\beta$; according to eq. (v), $k$ is the value of the sensation difference $\Delta \gamma$ that corresponds to $\beta=e$, where $e$ is the base of the natural logarithm (the natural logarithm of $e$ is 1); according to eq. (vii), $\Delta \gamma=k$ when $\beta_{0}: \beta=1: e$ (the natural logarithm of 1 
is 0$)^{5}$ Thus, without an underlying causal connection, a mere functional relation is not sufficient to establish a quantitative comparison.

It is true that, as Fechner points out, even in physics a functional relationship does not always imply a causal relationship (Fechner 1882, p. 227); the frequency of a pendulum is a function of the pendulum's length, the orbital velocity of a planet of its distance from the sun, etc.; however, no causal relationship between these pair of quantities is implied (Elsas 1886b, p. 65). However, according to Elsas, at a deeper level, there must always be "a causal condition at the basis of the functional connection" (1886b, p. 65); in the cases just mentioned, it is the gravitational force (cf. Heidelberger [1993] 2004, p. 230ff). Thus there are only two alternatives. If, as Fechner claims, there is no causal relationship between the body and the mind, then the connection between stimulus and sensation cannot be expressed through a mathematical equation; the latter is not measurable. What Fechner constructed is only "pseudo-physics [Scheinphysik]" (Elsas 1886b, p. 67). If Weber's law were really an expression of the causal connection between stimulus and sensation, then Fechner's psychophysics would be a "real physics of the soul" (Elsas 1886b, p. 64). However, the existence of a causal relationship between stimulus and sensation, the body and soul, seems to be incompatible with energy conservation.

Thus, Elsas did not seem to allow for any appeal against his draconian statement: "Mathematical psychology, psychophysics and physiological psychology_three absurd expressions [Bezeichnungen]!" (Elsas 1886b, p. 79). The only escape, in Elsas' view-as Stadler had already suggested (Stadler 1878, p. 223; cf. Elsas 1886b, p. 74n20) —is to consider the causal relationship not between stimulus and sensation, but between stimulus and the peripheral/central nervous system: "then psychophysics becomes nothing but common physiology" (Elsas 1886b). As Elsas put it in the opening of a contemporary semi-popular introduction to acoustics, "[t]he object of sensations is always motion, which is transmitted to the nerves of our sense organs and through them is transported to our brain" (1886a, p. 1). We can say that hearing is different from sight, but we are not able to express in words this difference between sound and color. The only difference is in the types of motion that excite our sense organs; this difference is investigated by physics, "the task of which is to reduce the natural phenomena to motion" (1886a, p. 1). If one cannot make use of the concepts of force and motion, Elsas concludes rather narrow-mindedly, then no mathematics can be applied (1886b, p. 70). Sensation is not an object of scientific knowledge; it is not a part of nature; it has no reality

5. Recall that eq. (vii) is derived from $\gamma_{0}-\gamma=k \log \beta_{0}-\log \beta$. 
for the mathematical physicist; it cannot be treated mathematically as a measurable quantity (Elsas 1886b, p. 70).

\subsection{With or Against Cohen}

The role of sensation, Elsas concluded in his book, is epistemological. Sensation expresses the need to go beyond measurable extended quantities, to look at that something which is extended, and provides physical content to extension. This is, in Cohen's interpretation, what Kant had tried to express in the Anticipations of Perception, by connecting sensation, reality and intensive magnitude (Elsas 1886b, pp. 75f). E.g., as Elsas put it, velocity as a physical concept cannot be reduced to the differential quotient of space and time: it "is an intensive magnitude; the extensive quotient is only the mathematical expression of it but not an adequate one" (1886b, p. 68). In this way Elsas attempted to rephrase Cohen's infamously obscure prose in a language more familiar to science practitioners: "At least I hope that I have not changed something essential in this translation from the scholastic language of the philosophers into the one of the physicists" (Elsas 1886b, p. 76).

These remarks seem to be tacked on at the end of the book, rather than part of its main line of argument. ${ }^{6}$ However, they show that, in contrast to Stadler, Elsas had at least tried to embrace Cohen's new course. This was far from obvious. In contrast, Müller's attitude towards Cohen's work dramatically changed after the latter's 1883 book. In his 1886 habilitation writing, Das Problem der Continuität im Mathematik und Mechanik (Müller 1886), Müller became highly critical of Cohen's connection of the differential and the intensive magnitude. Interestingly, according to Müller, the "difficulties which Cohen got tangled up in the development of his thought" should be traced to the fact that he was misled by the analogy with psychophysics. Cohen, in Müller's view, "committed the same mistake that psycho-physics fell into" (1886, p. 96n.); he attributed "to something which, like the differential, is not a real object [...], a magnitude, indeed an intensive magnitude" (1886, p. 96n). Müller's remark is important insofar as it confirms that Cohen, more or less consciously, tried to transfer the approach that psychophysics had applied to the intensive magnitude of psychological quantities to the intensive magnitude of physical ones. Just as psychophysics wanted to

6. I disagree with Heidelberger's claim that Elsas "associates this [his critique of psychophysics] with Cohen's theory of infinitesimals" (Heidelberger [1993] 2004, p. 230). I suspect that Elsas's emphasis on "role that causality plays in measurement" (Heidelberger [1993] 2004, p. 229) was formulated before (possibly already in the answer to the 1881 Preisaufgabe) and independently from Cohen's 1883 book; only as an afterthought Elsas tried to give some Cohenian flavor to his line of argument. 
measure sensation as the accumulation of infinitesimally small sensation increments, Cohen wanted to present the production of finite quantities in physics as the infinite summation of infinitesimal quantities. However, as Müller pointed out, this is "a complete misunderstanding of the method of limits" (1886, p. 96n).

Müller's attacks, who "for some years was part of our restricted circle," came as a surprise (Elsas to Lasswitz, January 7, 1887; CN, Br. 11, 171). Elsas pointed this out in a letter to Kurd Lasswitz at the beginning of 1887, when he thanked the latter for the positive review (Lasswitz 1887a) of his psychophysics booklet in the Deutsche Literaturzeitung - Germany's most important general review journal. Elsas did not want to influence Lasswitz's judgment, whom Natorp had asked to review Müller's book for the Philosophische Monatshefte (Natorp to Lasswitz, September 24, 1886; CN, Br. 10, 170). However, he did not hide his disappointment towards Müller's behavior, after all Cohen had done for him (Elsas to Lasswitz, January 7, 1887; CN, Br. 11, 171). Nevertheless, he also had to admit the difficulties of fully embracing Cohen's approach: "Often I myself am not sure if Cohen really means and says what I read off or hear from his elliptic remarks" (Elsas to Lasswitz, January 7, 1887; $\mathrm{CN}, \mathrm{Br} .11,172)$. Elsas expressed a similar uneasiness a month later in another letter to Lasswitz (Elsas to Lasswitz, Febuary 8, 1887; CN, Br. 12, 182).

Lasswitz (1848-1910) was a high school teacher from Gotha who was working on the history and philosophy of atomism (Lasswitz 1878, 1884). He became interested in Cohen's work on the history of the infinitesimal calculus (Lasswitz 1885a, 1885b), possibly after a correspondence (Eccarius 1985) with one of Cohen's most renowned mathematician critics, Georg Cantor (Cantor 1884). Lasswitz's review of Müller's book became a long paper entitled "Das Problem der Continuität" (Lasswitz 1888). Besides addressing some of Müller's criticisms (Lasswitz 1888, pp. 24-8; see also Lasswitz 1887b), Lasswitz mostly gave his take on Cohen's connection between the differential and intensive magnitudes. Motion, he explained, as a change of space extension in a certain time span, has no physical reality. In every instant, there is no change of position, thus no motion. The physical reality of motion has to be searched for in something that is beyond extension, but possesses a greater or smaller ability to generate a determinate motion (Lasswitz 1888, p. 19ff). However, this intensity of motion finds mathematical expression in the differential function $d y=f^{\prime}(d x)$, and not in the differential $d x$, as Cohen misleadingly claimed (Lasswitz 1888, pp. 29-31). Yet Müller remained unconvinced. He replied to Lasswitz in October 1887, calling Cohen's work on the infinitesimal method "one of the most monstrous births in the entire history of philosophy" (Müller to Lasswitz, Octtober 26, 1887 ; CN, Br. 13, 172). Müller died a few months later of a severe lung disease, so that no further discussion was possible. 


\subsection{The Fechner-Elsas Debate}

Toward the end of 1887, Elsas sent Lasswitz detailed comments on the latter's "essay on the problem of continuity" (Elsas to Lasswitz, Nov. 9, 1887; CN, Br. 14, 179). He also took the opportunity to announce that he had finished another paper on psychophysics for the Philosophische Monatshefte: "Even though I'm very busy with accumulators and galvanometers, I did not want to hesitate too long in answering Fechner's paper in the Philos. Studien" (Elsas to Lasswitz, Nov. 9, 1887; CN, Br. 14, 182). In fact, the indefatigable Fechner again made the effort to answer some of his critics, Elsas himself and Alfred Köhler (1886), in Wilhelm Wundt's journal (Fechner 1888), which in spite of the title, mainly dealt with empirical psychology. Fechner was 86 years old, and as he recognized halfjokingly, this may have been the last time that he was able to defend his own scientific creature (Fechner 1888, p. 163).

Fechner's reply to Elsas is too long and detailed to be dealt with here. However, a point is worth noticing. Here Fechner repeated, even more clearly than in Müller's review, that the assumption that difference sensations are proportional to sensation differences was merely the "simplest hypothesis" (Fechner 1888, pp. 171, 174) from which he could choose (cf. also Fechner 1888, pp. $147 \mathrm{ff}$ for more details). Fechner calls it the Unterschiedshypothese, the difference hypothesis (j.n.d.s are proportional to sensation differences). Such a hypothesis is acceptable inasmuch as it is implied by the empirically confirmed logarithmic law. Fechner claims that there is at least one other simple alternative one can think of, which he calls the Verbältnishypothese, the ratio hypothesis (j.n.d.s are proportional to sensation ratios). This hypothesis, which was adopted by Plateau and Brentano (and supported by Elsas himself), leads however to a power law which, Fechner claimed, is empirically wrong (but see of course Stevens 1961).

However, Fechner had to concede Elsas' point that, if one assumes the difference hypothesis, eqs. (ii), (v) and (vii) are indeed incompatible "as the author [Elsas] has correctly shown on p. 17" (Fechner 1888, p. 167). However, Fechner had a quite interesting response. He claimed that the proportionality between sensation differences and difference sensations applies only to the differential equation (iii), and not to the finite equation (ii), an equation that he actually never wrote: "where for God's sake did I ever put forward equation [ii]?” (Fechner 1888, p. 168). Thus, in the reply to Elsas, Fechner may have revealed a quite astonishing fact, which, NeoKantianism aside, is relevant to Fechner scholarship in general (cf. Scheerer 1987). Fechner did not regard eq. (iii) as an approximation derived from the empirically verified eq. (ii), but vice versa: he saw eq. (ii) as the approximation of the exact eq. (iii) (cf. Dzhafarov and Colonius 1999). After all, this is 
confirmed by the fact that, in the Zend-Avesta, he had introduced the differential equation as an exact equation before he knew about Weber's findings (Fechner 1851). Thus Fechner's rebuttal to Elsas reveals that, in contrast to what most of Fechner's critics had assumed, the passage from Weber's law (ii) to the differential equation (iii) via the infamous mathematical auxiliary principle was not the spine of Fechner's derivation of the logarithmic formula.

In his reply, Elsas (1888a) had to admit that he could not find eq. (ii) in any of Fechner's writings (Elsas 1888a, p. 132n1). However, he was not particularly impressed. Even if I cannot do full justice of Elsas' thirty-page defense here, I suspect that he did not fully realize the importance of Fechner's counter-move. Elsas went on to criticize Fechner's derivation starting from a more general finite formula, again attacking the mathematical auxiliary principle, that, he claimed, Fechner used more as the wand of a magician rather than the tool of a craftsman (Elsas 1888a, p. 134). Elsas showed that one can actually obtain the logarithmic equation (vii) without magically deriving it from the finite formula via the auxiliary principle. In this setting, the proportionality factor $k$ becomes something that has to be obtained by differentiation of the logarithmic equation (v) and not introduced from the outset in Weber's eq. (ii) (Elsas 1888a, p. 136). Thus, the proportionality between j.n. difference sensations and sensation differences is strictly valid only "when the change of $[\gamma]$ and $[\beta]$ are infinitesimally small" (Elsas 1888a, p. 137). This, however, might have been the exact point Fechner wanted to make. The constant $k$ is derived from the logarithmic law and not taken from the empirical Weber law. It is the logarithmic law itself, taken as measurement formula that defines the relation between two units of measure (Heidelberger [1993] 2004, p. 206). Elsas did not seem to realize that this might have fended off many neo-Kantian objections.

However, for Elsas, the essential philosophical point has not changed. Let's concede to Fechner that the number of sensation differences becomes approximately proportional to the number of difference sensations, the smaller the stimuli difference becomes. Still, Fechner uncritically assumed that one can measure sensation by adding up sensation differences. However, it is far from obvious that sensation has such an additive structure (Elsas 1888a, p. 139ff). Musical intervals are certainly quantitatively comparable (a 4th is smaller than a 5th), but cannot be meaningfully added (a 5 th plus a 4th equals an octave) (Elsas 1888a, p. 140). Fechner, Elsas points out, wants us to believe that sensation is "something spiritual, psychical, and nevertheless has magnitude that can be connected additively with other magnitudes of the same types"; but Elsas simply could not understand this: "[f]undamental epistemological views prevent me from doing so" 
(1888a, p. 143). The epistemological difference between Fechner and Elsas, I think, boils down to the following: the transformation of a class of intensities into a class of measurable intensities was for Fechner a matter of definition, whereas for Elsas it was a matter of physics. Thus, for Fechner the difference hypothesis was a better definition than the alternative, whereas Elsas spent the rest of the paper trying to prove that the ratio hypothesis was physically superior.

When Elsas' rebuttal appeared in the 1888 issue of the Philosophische Monatshefte, Fechner had already passed away. "The previous remarks," Elsas acknowledged in a short postscript to his paper, "are no laurel wreath and no palm branches worth being placed on Fechner's fresh grave" (1888a, p. 155). They were written as Fechner was still alive and still speak as if he were alive, "since Fechner's contribution to science will never die” (1888a, p. 155). Elsas' note was not simply rhetorical. In the same year, Elsas dedicated a long homage to the great scientist in the national-liberal magazine Die Grenzboten (1888b). Granting Fechner the honors of war, Elsas now celebrated Fechner's work as the first serious critical reflection on the measurability of mental contents (cf. 1888a, p. 114). However, Elsas' conciliatory remarks could not and probably were not meant to bridge the wide philosophical divide that separated him from Fechner. For Fechner, measuring sensations was a worthy enterprise, because as Heidelberger has pointed out, he ultimately conceived of physical measurement itself as nothing but the refinement of the resolution power of sensations via measuring apparatuses (Heidelberger [1993] 2004, sec. 6.5 and in particular pp. 246); but this point of view was fundamentally foreign to Elsas, who, like most 19 th century physicists, regarded sensations as nothing but anthropomorphic slags that physical measurement was meant to get rid of.

\section{Conclusion: From the Cohen Circle to the Marburg School}

In those years, the Marburg critique of scientific psychology was taking a more philosophically sophisticated form in Natorp's hands (Natorp 1887 , 1888, 1893; cf. Luft 2009); Elsas' technical objections against psychophysics were largely forgotten. They are mentioned, albeit rarely, in the historical literature on psychophysics and measurement theory (Heidelberger [1993] 2004; Darrigol 2003), though, surprisingly, never in the literature on Marburg Neo-Kantianism. Yet Elsas' work on the topic was respected in the scientific community. Beside Fechner's own detailed reply, Elsas' booklet deserved the mention (alongside Paul du Bois-Reymond's Allgemeine Functionentheorie [Bois-Reymond 1882]) of his teacher Helmholtz in his 1887 paper, Zäblen und Messen (Helmholtz 1887). The reference to Elsas reveals that Helmholtz's paper-which is now regarded as a classic contribution 
to the philosophical/mathematical reflection on the notion of measurement in science (Darrigol 2003) — was probably occasioned by the question of the measurability of sensation (Heidelberger 1993). Thus, the publications of the early Cohen circle were perceived as contributions to this debate. By contrast, Cohen's commentaries on Helmholtz's 1887 paper (Cohen 1888) — which appeared in the same 1888 volume of the Philosophische Monatshefte as Elsas' rebuttal to Fechner-give the impression that he did not fully recognize the philosophical importance of the issue at stake. Elsas' causal theory of measurement is not even mentioned; most of all, Cohen, intent on attacking Helmholtz's naive empiricism, does not seem to appreciate the implications of the latter's analysis of the conditions governing extensive magnitudes; similarly he quickly passed over Helmholtz's definition of intensive magnitude as coefficients (measurable only as ratios between extensive magnitudes) (Helmholtz 1887, p. 47). Instead, Cohen concluded the paper by plugging his own work on the intensive magnitude as infinitesimals (Cohen 1888 , p. 273), which seems rather out of context.

In the following years, Elsas, a close friend of Heinrich Hertz (Fölsing 1997, p. 423), published extensively on the new Maxwell-Hertz theory; he introduced an autonomous circuit breaker, alternative to the Wagner hammer (Elsas 1889b), suggested methods to measure electric resistance (Elsas 1891c) and the dielectric constants (Elsas 1891b), etc. Howeverdespite Hertz's advice not to go astray "in swampy borderlands" like psychophysics (Hertz to Elsas, February 10, 1889; cited in Fölsing 1997, p. 423) - he did not forgo some interesting philosophical escapades (Elsas 1889a). After Hertz failed to find a position for him in Bonn (Fölsing 1997, pp. 429), he became an extraordinary professor without salary in Marburg. In a difficult financial situation (Lasswitz to Natorp, June 4, 1895; cited in Holzhey 1986, p. 24n89), he died prematurely in 1895 of pulmonary tuberculosis.

Cohen's funeral oration (Cohen 1895) in his honor is also a recollection of the interdisciplinary atmosphere of the early Marburg circle. If it was Cohen's early interest in psychophysics that contributed to gathering this small group around his Marburg chair, it was Cohen's infinitesimal turn that had fragmented and eventually dissolved this group. It was not just the traitor Müller that did not follow Cohen's approach, but also the sincere friend Stadler—since 1892 a professor at the ETH Zurich (Beller 2000)—; Elsas attempted to translate it for non-philosophically-trained readers, but ultimately he was himself not fully convinced. It was the newcomer Lasswitz, though never an official member of the Marburg group, who was the first to try to implement a watered-down version of Cohen's connection between the intensive and infinitesimal in his own successful work as a historian of science (Lasswitz 1890; see Natorp 1891; Elsas 1891a), even if his efforts were not to Cohen's complete satisfaction (Cohen 1896, p. XLVII). 
Precisely this combination of transcendental philosophy and history of science became the trademark of the Marburg community at the turn of century. At the end of 1890s - after Natorp became full professor - Cohen started to talk cautiously of a little school that was forming in Marburg (Cohen to Natorp, April 19, 1897; CN, Br. 42, 243 and Cohen to Althoff, May 8, 1897; CN, Br. 43, 244). The titles of the Preisaufgaben launched in those years testify to the historical interests that dominated this group: Aristotle and mathematics in 1894/95 (Albert Görland), Leibniz's foundation of mathematics and natural science in 1896/97 (Ernst Cassirer), Galileo's Mechanics in 1900/1901 (Enrico DePortu), and Faraday's concept of matter in 1901/1903 (Otto Buek) (cf. Holzhey 1986, vol. 1, p. 382). The prize essays were transformed into often excellent dissertations and monographs (Görland 1899; Cassirer 1902; Portu 1904; Buek 1904) which represent some early examples of the Marburg-style integration of history of philosophy and history of science which soon found its most successful expression in Cassirer's Erkenntnisproblem (Cassirer 1906a).

The interests in psychophysics - the attempt "to make sensation arise and increase till it comes to consciousness and becomes integral" (Cohen 1902, p. 441)—faded in the background. However, interestingly, it did not completely disappear. The Preisaufgabe suggested by Natorp in 1904/1906 concerned the problem of sensation in modern psychology. The prize remained unassigned. However, in 1906 Johannes Paulsen finished a dissertation on Fechner's concept of sensation under the guidance of Cohen and Natorp (Paulsen 1906-1907). A longer version of it was published as a booklet (Paulsen 1907) in the first volume of the Philosophische Arbeiten, the series edited by Cohen and Natorp that was meant to represent (Cassirer 1906b, pp. I-III) what people began to call the Marburg school (cf. Cohen 1913-1914). Even if Paulsen's work does not add anything new to the previous neo-Kantian criticisms of psychophysics (see also Natorp 1912a), it shows that the issue was still considered part of the legacy of the Marburg community. After all, as Cohen himself recognized in his Nachruf for Stadler, it was the latter's critique of Fechner's logarithmic formula that led him to take a new course in his 1883 book (Cohen 1910a). It is probably not just by chance that a contribution of Paulsen's (1912) was included in the 1912 Festshrift for Cohen's seventieth birthday, testifying to the role that psychophysics played in the evolution of the latter's thought.

As we mentioned at the opening of the present paper, this was precisely what Cassirer suggested in his article (Cassirer 1912) for the 1912 special issue of the Kant-Studien that was prepared for the celebration of Cohen's retirement. Cohen's interest in the problem of sensation in Kant's Anticipations of Perception, Cassirer explained, led to the notion of stimulus as objectified sensation; the latter in turn must be ultimately thought of as a motion. It was the question of the possibility of motion as an object of 
scientific knowledge that ultimately led to Cohen's interest in the history of the infinitesimal method (Cassirer 1912, p. 260). Cohen's Das Princip der Infinitesimal-Methode, despite being unsuccessful as a scholarly work on the infinitesimal calculus, exemplified that peculiar amalgam of history and philosophy of science that became one of the trademarks of the Marburg school (cf. Giovanelli 2016). However, as we have tried to show, the appearance of that book also interrupted a fruitful discussion on measurability in science that the Cohen circle had initiated. This discussion seems to have left no trace in the major Marburg contributions to philosophy of science (Cassirer 1910; Natorp 1910). It was only in the 1930s, that Cassirer returned, although briefly, to the issue of measurement in physics in his "Determinismus und Indeterminismus" (Cassirer 1936). However, he could resume the discussion from the exact point where the 19th century had left it: physical measurement, Cassirer insisted, is not simply the emancipation of sensation from the limits imposed by "the fundamental psychophysical law", "the FechnerWeber law" (Cassirer 1936, p. 42; trans. 1956, p. 32) by means of measuring apparatuses. The physical world, Cassirer claimed, is not a mere quantitative refinement of the sensible world; it is a qualitatively different world, a world of shadows, a symbolic construction that takes the place of the fullness and color of the sensible world (Cassirer 1936, p. 41; trans. 1956, p. 43).

\section{Abbreviations}

A Immanuel Kant. Critik der reinen Vernunft. 1st ed. Riga: Johann Friedrich Hartknoch, 1781. Repr. in Ak., 4.

Ak. Immanuel Kant. Kant's gesammelte Schriften. Edited by Preussische Akademie der Wissenschaften, Berlin- Brandenburgische Akademie der Wissenschaften, and Akademie der Wissenschaften in Göttingen. 29 vols. Berlin: Reimer, 1900-.

B Immanuel Kant. Critik der reinen Vernunft. 2nd ed. Riga: Johann Friedrich Hartknoch, 1787. Repr. in Ak., 3.

CN Helmut Holzhey. Cohen und Natorp. Vol. 2. Basel: Schwabe, 1986.

CW Hermann Cohen. Werke. Edited by Helmut Holzhey. 15 vols. Hildesheim: Olms, 1977-.

ECW Ernst Cassirer. Gesammelte Werke. Hamburger Ausgabe. Edited by Birgit Recki. 26 vols. Hamburg: Meiner, 1998-.

\section{References}

Beiser, Frederick C. 2014. The Genesis of Neo-Kantianism, 1796-1880. Oxford: Oxford University Press.

Beller, Mara. 2000. Kant's Impact on Einstein's Thought. Pp. 83-106 in Einstein: The Formative Years 1879-1909. Edited by Don Howard and John Stachel. Boston: Birkhäuser. 
Bois-Reymond, Paul Du. 1882. Allgemeine Functionentheorie. Tübingen: Laupp.

Brentano, Franz. 1874. Psychologie Vom Empirischen Standpunkt. Leipzig: Duncker \& Humblot.

Buek, Otto. 1904. "Die Atomistik und Faradays Begriff der Materie." Archiv für Geschichte der Philosophie 18: 65-139.

Cantor, Georg. 1884. "Review of Cohen, Das Princip der Infinitesimal-Methode (Cohen 1883)." Deutsche Literaturzeitung 5: 266-8.

Cassirer, Ernst. 1902. Leibniz' System in seinen wissenschaftlichen Grundlagen. Marburg: Elwert. Repr. in ECW, Vol. 1.

Cassirer, Ernst. 1906a. Das Erkenntnisproblem in der Philosophie und Wissenschaft der neueren Zeit. Vol. 1. Berlin: B. Cassirer. Repr. in ECW, Vol. 2.

Cassirer, Ernst. 1906b. Der kritische Idealismus und die Philosophie des "gesunden Menschenverstandes." Giessen: Töpelmann.

Cassirer, Ernst. 1910. Substanzbegriff und Funktionsbegriff: Untersuchungen über die Grundfragen der Erkenntniskritik. Berlin: Bruno Cassirer. Repr. in ECW, Vol. 6.

Cassirer, Ernst. 1912. "Hermann Cohen und die Erneuerung der Kantischen Philosophie". Kant-Studien 17: 252-273. Repr. in ECW, Vol. 9, 119-138.

Cassirer, Ernst. 1936. "Determinismus und Indeterminismus in der modernen Physik: Historische und systematische Studien zum Kausalproblem". Göteborgs Högskolas Årsskrift 42 (3). Repr. in ECW, Vol. 19.

Cassirer, Ernst. 1956. Determinism and Indeterminism in Modern physics: Historical and Systematic Studies of the Problem of Causality. New Haven: Yale University Press.

Cohen, Hermann. 1868. "Mythologische Vorstellungen von Gott und Seele." Zeitschrift Völkerpsychologie und Sprach-wissenschaft 5: 396-434. Repr. in CW, Vol. 12, pp. 271-343.

Cohen, Hermann. 1871. Kants Theorie der Erfahrung. 1st ed. Berlin: Dümmler. Repr. in in CW, vol. 1/III.

Cohen, Hermann. 1877. Kants Begründung der Ethik. 1st ed. Berlin: Dümmler. The 2nd edition (Cohen 1910b) is reprinted in CW, vol. 2.

Cohen, Hermann. 1883. Das Princip der Infinitesimal-Methode und seine Geschichte: Ein Kapitel zur Grundlegung der Erkenntnis-skritik. Berlin: Dümmler. Repr. in in CW, vol. 5/I.

Cohen, Hermann. 1885. Kants Theorie der Erfahrung. 2nd ed. Berlin: Dümmler. Repr. in in CW, vol. $1 /$ I.

Cohen, Hermann. 1888. "Jubiläums-Betrachtungen." Philosophische Monatshefte 24: 257-291. Repr. in Cohen 1928, 1:397-431.

Cohen, Hermann. 1895. "Worte an der Bahre von Adolf Elsas, Professor der Physik an der Universität Marburg." Gesprochen im Trauerhause am 16. Mai 1895. In Cohen 1928, pp. 396-397. 
Cohen, Hermann. 1896. "Einleitung mit kritischem Nachtrag." In Geschichte des Materialismus und Kritik seiner Bedeutung in der Gegenwart, 5th edited by Friedrich Albert Lange. Leipzig: Baedeker. Repr. in CW, Vol. 5/2.

Cohen, Hermann. 1902. Logik der reinen Erkenntnis. Berlin: B. Cassirer. Repr. in CW, vol. 6.

Cohen, Hermann. 1910a. "August Stadler: Ein Nachruf." Kant-Studien 15: 403-420. Repr. in CW, vol. 15, 513-542.

Cohen, Hermann. 1910b. Kants Begründung der Etbik: nebst ibren Anwendungen auf Recht, Religion und Geschichte. 2nd edn. Berlin: B. Cassirer.

Cohen, Hermann. 1913-1914. Paul Natorp: Zu seinem 60. Geburtstag. Pp. 466-470 in Cohen 1928.

Cohen, Hermann. 1928. Schriften zur Philosophie und Zeitgeschichte, eds. Albert Görland and Ernst Cassirer. Berlin: B. Cassirer.

Cohen, Hermann. 2015. Briefe an August Stadler. Edited by Hartwig Widebach. Basel: Schwabe.

Darrigol, Olivier. 2003. "Number and Measure: Hermann Von Helmholtz at the Crossroads of Mathematics, Physics, and Psychology." Studies in the History of the Philosophy of Science 34: 515-73.

Delbœuf, Joseph. 1873. Études psychophysiques sur la mesure des sensations. Bruxelles: Muquardt.

Delbœuf, Joseph. 1878. "La loi psychophysique et le nouveau livre de Fechner." Revue philosophique de la France et de l'etranger 5: 34-63.

Delezenne, Charles Edouard Joseph. 1826. "Mémoire sur les valeurs numériques des notes de la gamme." Recueil des travaux de la Societè des Sciences de l'Agriculture et des Arts de Lille 1826 et premier semestre 1827 4: 1-56.

Dzhafarov, Ehtibar N., and Hans Colonius. 1999. "Fechnerian Metrics in Unidimensional and Multidimensional Stimulus Spaces." Psychonomic Bulletin E Review 6 (2): 239-268.

Eccarius, Wolfgang. 1985. "Georg Cantor und Kurd Laßwitz: Briefe zur Philosophie des Unendlichen." NTM - Schriftenreihe für Geschichte der Naturwissenschaften, Technik und Medizin 22 (1): 29-52.

Elsas, Adolf. 1881. Ueber erzwungene Schwingungen weicher Fäden. Würzburg: Elberfeld / Fassbender.

Elsas, Adolf. 1882. Untersuchungen über erzwungene Membranschwingungen. Marburg: Blochmann \& Sohn.

Elsas, Adolf. 1883a. "Review of Müller, Das Axiom der Psychophysik (Müller 1882)." Zeitschrift für Philosophie und Philosophische Kritik 83: 126-134.

Elsas, Adolf. 1883b. "Untersuchungen über erzwungene Schwingungen von Platten." Annalen der Physik und Chemie new 20 (11): 468-484.

Elsas, Adolf. 1884. "Review of Cohen, Das Princip der Infinitesimal-Methode (Cohen 1883)." Philosophische Monatshefte 20: 556-560. 
Elsas, Adolf. 1885a. "Bemerkungen zu der Abhandlung des Herrn F. Melde: Akustische Experimentaluntersuchungen." Annalen der Physik und Chemie new 25 (8): 676-677.

Elsas, Adolf. 1885b. "Review of Stadler, Kants Theorie der Materie (Stadler 1883)." Philosophische Monatshefte 21: 144-160.

Elsas, Adolf. 1886a. Der Schall: Eine populäre Darstellung der physikalischen Akustik mit besonderer Berücksichtigung der Musik. Leipzig/Prag: Freytag / Tempsky.

Elsas, Adolf. 1886b. Über die Psychophysik: Physikalische und erkenntnisstheoretische Betrachtungen. Marburg: Elwert.

Elsas, Adolf. 1886c. "Ueber die Nobili'schen Farbenringe und verwandte electrochemische Erscheinungen." Annalen der Physik und Chemie new 29 (10): 331-343.

Elsas, Adolf. 1887. "Ueber die Nobili'schen Farbenringe und verwandte electrochemische Erscheinungen." Annalen der Physik und Chemie new 30 (4): 620-630.

Elsas, Adolf. 1888a. "Die Deutung der psychophysischen Gesetze." Philosophische Monatshefte 24: 129-155.

Elsas, Adolf. 1888b. "Zum Andenken Gustav Theodor Fechners." Die Grenzboten: Zeitscbrift für Politik, Literatur und Kunst 47 (2): 73-80, 113-124.

Elsas, Adolf. 1889a. "Kritische Betrachtungen über die Wahrscheinlichkeitsrechnung." Philosophische Monatshefte 25: 557-584.

Elsas, Adolf. 1889b. "Ueber einen selbstthätigen Stromunterbrecher." Annalen der Physik und Chemie new 37 (8): 675-680.

Elsas, Adolf. 1891a. "Review of Lasswitz, Geschichte der Atomistik (Lasswitz 1890)." Zeitschrift für Philosophie und Philosophische Kritik 99: 290-303.

Elsas, Adolf. 1891b. "Ueber eine neue Methode zur Bestimmung von Dielectricitätsconstanten." Annalen der Physik und Chemie new 280 (12): 654-665.

Elsas, Adolf. 1891c. "Ueber Widerstandsmessungen mit Hülfe des Telephons." Annalen der Physik und Chemie 44 (12): 666-680.

Fechner, Gustav Theodor. 1851. Zend-Avesta oder über die Dinge des Himmels und des Jenseits: Vom Standpunkt der Naturbetrachtung 3 vols. Hamburg: Voss.

Fechner, Gustav Theodor. 1860. Elemente der Psychophysik. 2 vols. Leipzig: Breitkopf \& Härtel. First volume translated in Fechner 1966.

Fechner, Gustav Theodor. 1877. In Sachen der Psychophysik. Leipzig: Breitkopf und Härtel.

Fechner, Gustav Theodor. 1882. Revision der Hauptpuncte der Psychophysik. Leipzig: Breitkopf \& Härtel.

Fechner, Gustav Theodor. 1888. "Ueber die psychischen Maßprincipien und das Weber'sche Gesetz: Discussion mit Elsas und Köhler.” Edited 
by Wilhelm Wundt. Philosophische Studien 4: 161-230. Partially translated in Fechner 1987.

Fechner, Gustav Theodor. 1966. Elements of Psychophysics, ed. Davis H. Howes and Edwin G. Boring, trans. Helmut E. Adler. With an Introduction by Edwin G. Boring. Vol. 1. New York: Holt, Rinehart / Winston.

Fechner, Gustav Theodor. 1987. "My Own Viewpoint on Mental Measurement (1887)," trans. Eckart Scheerer. Psychological Research 49 (4): 213-219.

Fölsing, Albrecht. 1997. Heinrich Hertz: eine Biographie. Hamburg: Hoffmann und Campe.

Giovanelli, Marco. 2016. "Hermann Cohen's Das Princip der InfinitesimalMethode: The History of an Unsuccessful Book." Studies in History and Philosophy of Science Part A 58: 9-23.

Görland, Albert. 1899. Aristoteles und die Mathematik. Marburg: Elwert.

Heidelberger, Michael. 1993. "Fechner's Impact for Measurement Theory." Behavioral and Brain Sciences 16 (1): 146-148.

Heidelberger, Michael. [1993] 2004. Nature from Within: Gustav Theodor Fechner and His Psychophysical Worldview. Pittsburgh: University of Pittsburgh Press.

Heidelberger, Michael. 2010. "Functional Relations and Causality in Fechner and Mach." Philosopbical Psychology 23 (2): 163-172.

Helmholtz, Hermann von. 1867. Handbuch der physiologischen Optik. Leipzig: Voss.

Helmholtz, Hermann von. 1877. Die Lehre von den Tonempfindungen als physiologische Grundlage für die Theorie der Musik. Braunschweig: Vieweg.

Helmholtz, Hermann von. 1887. Zäblen und Messen, erkenntnisstheoretisch betrachtet. Pp. 17-52 in Philosophische Aufsätze, Eduard Zeller zu seinem fünfzigjäbrigen Doctorjubiläum gewidmet. Leipzig: Fues.

Hering, Ewald. 1875. Zur Lehre von der Beziehung zwischen Leib und Seele: I. Mittheilung: Über Fechner's psychophysisches Gesetz. Sitzungsberichte der Kaiserlichen Akademie der Wissenschaften in Wien 72 (III Abt.): 310-348.

Holzhey, Helmut. 1986. Cohen und Natorp. 2 vols. Basel: Schwabe.

Kant, Immanuel. 1786. Metaphysische Anfangsgründe der Naturwissenschaft. Riga: Johann Friedrich Hartknoch. Repr. in Ak. 4:465-565.

Köhler, Alfred. 1886. "Ueber die hauptsächlichen Versuche einer mathematischen Formulirung des psychophysischen Gesetzes von Weber." Philosophische Studien 3: 572-642.

Kries, Johannes von. 1882. "Ueber die Messung intensiver Grössen und über das sogenannte psychophysische Gesetz." Vierteljahrsschrift für wissenschaftliche Philosophie 4 (3): 257-294. 
Lange, Friedrich Albert. 1866. Geschichte des Materialismus und Kritik seiner Bedeutung in der Gegenwart, 1st edn. Iserlohn: Baedeker.

Lange, Friedrich Albert. 1968. Über Politik und Philosophie: Briefe und Leitartikel 1862 bis 1875. Edited by Georg Eckert. Duisburg: Braun.

Lasswitz, Kurd. 1878. Atomistik und Kriticismus: Ein Beitrag zur erkenntnistheoretischen Grundlegung der Physik. Vieweg: Braunschweig.

Lasswitz, Kurd. 1884. "Giordano Bruno und die Atomistik." Vierteljabrsschrift für wissenschaftliche Philosophie 8: 18-55.

Lasswitz, Kurd. 1885a. "Review of Cohen, Das Princip der InfinitesimalMethode (Cohen 1883)." Vierteljahrsschrift für wissenschaftliche Philosophie und Soziologie 9: 494-503.

Lasswitz, Kurd. 1885b. "Zur Rechtfertigung der kinetischen Atomistik." Vierteljabrsschrift für wissenschaftliche Philosopbie 9: 137-161.

Lasswitz, Kurd. 1887a. "Review of Elsas, Über die Psychophysik (Elsas 1886b)." Deutsche Literaturzeitung 8: 3-4.

Lasswitz, Kurd. 1887b. "Review of Müller, Das Problem der Continuität im Mathematik und Mechanik (Müller 1886).” Deutsche Literaturzeitung 28: 1003-1004.

Lasswitz, Kurd. 1888. "Das Problem der Continuität." Philosophische Monatshefte 24: 9-36.

Lasswitz, Kurd. 1890. Geschichte der Atomistik 2 vols. Hamburg/Leipzig: Voss.

Luft, Sebastian. 2009. "Reconstruction and Reduction: Natorp and Husserl on Method and the Question of Subjectivity.” Pp. 59-91 in Makkreel and Luft 2009.

Luft, Sebastian. ed. 2015. The Neo-Kantian Reader. London/New York: Routledge.

Mach, Ernst. 1863. Vorträge über Psychophysik. Wien: Sommer.

Makkreel, Rudolf A., and Sebastian Luft, eds. 2009. Neo-Kantianism in Contemporary Philosophy. Bloomington: Indiana University Press.

Michell, Joel. 1999. Measurement in Psychology: Critical History of a Methodological Concept. Cambridge: Cambridge University Press.

Müller, Ferdinand August. 1882. Das Axiom der Psychophysik und die psychologische Bedeutung der Weber'schen Versuche. Marburg: Elwert.

Müller, Ferdinand August. 1886. Das Problem der Continuität im Mathematik und Mechanik: Historische und systematische Beiträge. Elwert: Marburg.

Müller, Georg Elias. 1878. Zur Grundlegung der Psychopbysik: Kritische Beiträge. Berlin: Grieben.

Natorp, Paul. 1881. "Leibniz und der Materialismus." First pub. in Helmut Holzhey, "Paul Natorp. Leibniz und der Materialismus (1881)." Studia Leibnitiana 17 (1): 3-14. 
Paulsen, Johannes. 1906-1907. "Der Begriff der Empfindung bei Fechner." Inauguraldissertation, Universität Marburg.

Paulsen, Johannes. 1907. Das Problem der Empfindung. Töpelmann: Giessen.

Paulsen, Johannes. 1912. "Ueber das empirische Verhältnis von Reiz und Empfindung." Pp. 123-135 in Philosophische Abhandlungen: Hermann Cohen zum 70. Geburtstag (4. Juli 1912) dargebracht, Berlin: B. Cassirer.

Philippi, E. 1883. "Review of Müller, Das Axiom der Psychophysik (Müller 1882)." Philosophische Monatshefte 19: 574-587.

Plateau, Joseph. 1872. "Sur la mesure des sensations physiques et sur la loi qui lie l'intensité de ces sensations à l'intensité de la cause excitante." Bulletins de l'Academie Royale des Sciences, des Lettres et des Beaux-Arts de Belgique, 2me Serie 34: 141-142.

Poma, Andrea. [1989] 1997. The Critical Philosophy of Hermann Cohen. Albany, NY: State University of New York Press.

Portu, Enrico Stefano Maria de. 1904. Galileis Begriff der Wissenschaft. Marburg: Elwert.

Scheerer, Eckart. 1987. “The Unknown Fechner.” Psychological Research 49 (4): 197-202.

Sieg, Ulrich. 1994. Aufstieg und Niedergang des Marburger Neukantianismus: Die Geschichte einer philosophischen Schulgemeinschaft. Würzburg: Königshausen und Neumann.

Stadler, August. 1874. Kants Teleologie und ibre erkenntnisstheoretische Bedeutung: Eine Untersuchung. Berlin: Dümmler.

Stadler, August. 1876. Die Grundsätze der reinen Erkenntnisstheorie in der Kantischen Philosophie: Kritische Darstellung. Leipzig: Hirzel.

Stadler, August. 1878. "Über die Ableitung des Psychophysischen Gesetzes." Philosophische Monatshefte 14: 215-23.

Stadler, August. 1880. "Das Gesetz der Stetigkeit bei Kant." Philosophische Monatshefte 16: 577-97.

Stadler, August. 1883. Kants Theorie der Materie. Leipzig: Hirzel.

Stevens, Stanley Smith. 1961. "To Honor Fechner and Repeal His Law." Science 133 (3446): 80-86.

Tannery, Jules. 1875a. "Correspondence: A propos du logarithme des sensations." La Revue scientifique 15: 876-877.

Tannery, Jules. 1875b. "La mesure des sensations: Réponses à propos du logarithme des sensations." La Revue scientifique 8: 1018-1020.

Weber, Ernst Heinrich. 1834. De pulsu, resorptione, auditu et tactu: Annotationes anatomicae et physiologicae. Leipzig: Koehler.

Weber, Ernst Heinrich. 1846. Tastsinn und Gemeingefübl. In Handwörterbuch der Physiologie mit Rücksicht auf physiologische Pathologie, Edited by Rudolph Wagner, 3.2:481-588. Braunschweig: Vieweg. 
Wundt, Wilhelm. 1874. Grundzüge der physiologischen Psychologie. Leipzig: Engelmann.

Zeller, Eduard. 1881. "Über die Messung psychischer Vorgänge.” Abhandlungen der Königlichen Akademie der Wissenschaften zu Berlin: Philosophisch-Historische Klasse 3: 1-16.

Zeller, Eduard. 1882. Einige weitere Bemerkungen über die Messung psychischer Vorgänge. Sitzungsberichte der Königlich Preussischen Akademie der Wissenschaften zu Berlin vol. 1:295-305. 